\title{
Chemical and microbiological quality of Anatolian Buffalo milk
}

\author{
Zeki Gürler, Yahya Kuyucuoğlu², and Şebnem Pamuk* \\ ${ }^{1}$ Afyon Kocatepe University, Faculty of Veterinary Medicine, Department of Food Hygiene, Department of Food Hygiene \\ and Techonology, Afyonkarahisar, Turkey. \\ ${ }^{2}$ Afyon Kocatepe University, Faculty of Veterinary Medicine, Department of Food Hygiene, Department of Microbiology,
} Afyonkarahisar, Turkey.

Accepted 19 March, 2013

\begin{abstract}
This study was carried out to determine the chemical and microbiological quality of Anatolian buffalo milk. A total of 120 Anatolian buffalo raw milk samples were collected monthly from Afyonkarahisar province, throughout the year for this study. In the chemical analysis of Anatolian buffalo milk samples the mean total solid value, non-solid fat, lipid, protein, lactose, ash and $\mathrm{pH}$ values were detected as $16.38 \%, 8.56 \%, 7.04 \%, 4.36 \%, 4.19 \%, 0.72 \%$ and 6.55 , respectively. Total bacteria count (TCA), coliform, lactic acid bacteria (LAB), Escherichia coli, Staphylococcus aureus and yeast-mold $\left(\log _{10} \mathrm{cfu} / \mathrm{ml}\right)$ levels in the milk samples were detected as $6.36,2.95,5.74,1.10,2.46$ and 2.63 , respectively.
\end{abstract}

Key words: Anatolian buffalo, buffalo milk, chemical quality, microbiological quality

\section{INTRODUCTION}

Milk is a white liquid produced by the mammary glands of mammals. It is the primary source of nutrition in the world with its high nutritious property. If convenient storage temperatures are not paid attention, milk becomes a suitable propagation medium for microorganisms due to its biochemical composition and high water activity. Milk can be easily contaminated and spoiled when it is produced in unhygienic environment. Milk quality is directly related to its composition and hygiene (Oliver et al., 2005; Parekh and Subhash, 2008). Buffalo milk has become a research subject and received increasing attention in many countries due to its rich nutrient content (Amarjit and Toshihiko, 2003). Compared to cow milk, buffalo milk has a richer taste due to its contents of milk fat, protein, lactose, total dry matter, vitamin and minerals. These properties allow a wider variety for buffalo milk as raw material for milk products like cheese, butter and icecream (Fundaro et al., 2001). There has been an increasing demand for cheese made of buffalo milk in many countries throughout the world as it is an organic product (Bilal et al., 2006).

Turkish Statistical Institute (TUIK, 2011) stated that total amount of milk collected between January 2010 and July 2011 period was 4.309.006 tons, and buffalo milk accounted for $0.26 \%$ of total milk amount according to the data of Packed Milk and Milk Products Society (ASUD, 2010). Buffaloes are grouped into riverin and swap types. Buffaloes in Turkey originate from Mediterranean buffaloes, a sub-group of river buffaloes and they are named Anatolian buffaloes (Atasever and Erdem, 2008). Buffalo production does not have an important share due to its limited commercial use in Turkey; however, it is reported that global buffalo milk was 90 million tons in 2009 and accounted for $13 \%$ of total milk production. The same report stated that more than $90 \%$ of total buffalo milk in the word is produced by India and Pakistan. It is also reported that buffalo milk is produced in different countries including China, Egypt, Bulgaria, Italy and Iran 
(Spanghero and Susmel, 1996). Interest and investments in buffalo milk in different countries is increasing each year due to its unique taste and nutritious content (Amarjit and Toshihiko, 2003). It is reported that especially the products made of buffalo milk like mozzarella cheese, cream, ice-cream and yogurt have commercial importance, as well (Fundaro et al., 2001). As in raw milk, microorganisms could rapidly propagate in buffalo milk due to rich nutrient content. In previous studies carried out on microbiological properties of buffalo milk (Sethi et al., 1994; Sekerden et al., 1999; Han et al., 2007), coliform bacteria, Escherichia coli, lactic acid bacteria, yeast-mold and Staphylococcus spp., were isolated from buffalo milk. Saprophytic microorganisms in milk could spoil buffalo milk, while the presence of pathogen bacteria could pose a potential health threat (Boycheva et al., 2002; Han et al., 2007). Contamination of milk and milk products mostly results from human factor and unhygienic conditions. Milk is generally contaminated in milk collection places. Coliform bacteria are microorganisms in natural flora of human and animal intestinal tract and they are accepted as indicators for bacteriological quality of milk and milk products (Chatterjee et al., 2006). Furthermore, the presence of these microorganisms indicates the possible existence of enteric pathogens that could threat public health. The most important indicators for microbiological quality include total bacteria number, coliform, yeast and mold quantity and detection of specific pathogens and their toxins (Szita et al., 2008). Among all microorganisms, $E$. coli is an organism that frequently contaminates foods. They generally exist in milk and milk products due to inadequate sanitation (Jayarao and Henning, 2001). The main thing in microbiological investigation of milk is the determination of contamination degree and number of indicator microorganisms. Coliform bacteria are reported to define the suitability of milk for human consumption (Wells et al., 1991)

Besides microbiological quality of milk, its physical and chemical properties are also quite important. Changes in milk composition depend on many factors like genetic, lactation time, daily variations, birth, alimentation type, age, udder cleaning and season (Kilic and Kilic, 1994; Haenlein, 2003). These factors greatly affect the quality and processing ability of cheese, butter and other milk products (Lindmark-Manson et al., 2000; Barron et al., 2001; Lindmark-Manson et al., 2003). Geographic region, climate conditions and lactation period are known as seasonal changes and cited among factors affecting milk composition (Sethi et al., 1994; Suman et al., 1998; Sekerden et al., 1999; Boycheva et al., 2002; Waldner et al., 2002). Especially, there is an inverse proportion between ambient temperature and protein and fat content of milk. Solid fats tend to decrease with increasing air temperature. Fat, protein, casein and all fractions of nitrogen are affected by seasonal change ( $\mathrm{Ng}$-Kwai-Hang et al., 1984; Lacroix et al., 1996). It is reported that high ambient temperature causes clot hardness to decrease and clot formation rate and clotting time to increase (Sevi et al., 2001). At high ambient temperatures, fat concentration decreases, while lactation period extends (Kilic and Kilic, 1994; Sekerden, 1999). Some studies reported that significant changes occur in the amounts of short chain fatty acids, and they become minimum in winter and maximum in summer (Lindmark-Manson et al., 2003; Lock and Garnsworthy, 2003).

The main physical characteristics of milk are defined as $\mathrm{pH}$ and electrical conductivity; in addition, fat content of buffalo milk is the most variable milk component, which is caused by genetic and specific factors (Harmon, 1994; Hartet et al., 1999; Ma et al., 2000). Carbohydrates are preliminary form of glucose circulating as lactose in milk. Lactose level is reported to affect milk amount to be produced and the level of short chain fatty acids (Fernando et al., 1983; Hamman and Gyodi, 1994). High fat and calorie contents besides dry matter are regarded as the superior and distinctive property of buffalo milk (Soysal, 2006). Buffalo milk is processed into many products including butter, cream, hard and soft cheese, ice-cream and yogurt (Bilal et al., 2006).

The aim of this study carried out in Afyonkarahisar Province, located in an important region for buffalo milk and milk products with dense buffalo presence, was to determine the chemical and microbiological qualities of seasonally collected buffalo milk samples and to investigate the effect of seasonal change on milk composition.

\section{MATERIALS AND METHODS}

\section{Milk samples}

A total of 120 raw milk samples were collected every month from 10 small sized family enterprises (farms had $\leq 10$ buffaloes) randomly selected in Afyonkarahisar Province, 10 samples from each, between September 2009 and August 2010. Two hundred and fifty milliliter $(250 \mathrm{ml})$ of milk samples were taken from producer under aseptic conditions and transferred in sterile bottles to laboratory in cold chain $4^{\circ} \mathrm{C}^{\prime}$ and then they were analyzed.

\section{Chemical analyses}

Fat, protein, lactose, total dry matter (DM) and ash contents of buffalo milk samples were determined by pre-calibrated LactoStar milk analysis device (FUNKE GERBER, Germany). $\mathrm{pH}$ values of milk samples were determined by InoLab ( $\mathrm{pH}$ Level $\mathrm{L}$ 01280054) $\mathrm{pH}$ meter device.

\section{Microbiological analyses}

In the analysis, $10 \mathrm{ml}$ of milk was taken from each milk sample and homogenized in sterile bags containing $90 \mathrm{ml}$ of sterile buffered peptone water for 1-2 min and then dilutions were prepared by $10^{8}$ and cultivations were performed. Cultivation was made on Plate Count Agar (Oxoid CM0325) using drop plate method in order to determine the number of mean total bacteria count (TCA) in the prepared dilutions (Anonymous, 2003). Violet Red Bile Agar (Oxoid$\mathrm{CM}$ 107) was used to determine coliform bacteria count and incubated under aerobic conditions at $37^{\circ} \mathrm{C}$ for $24 \mathrm{~h}$ (Anonymous, 1993). Cultivation was made on MRS Agar (Oxoid-CM 0361) for 
Table 1. Chemical analysis results of Anatolian Buffalo milk.

\begin{tabular}{lccccccc}
\hline Season & $\begin{array}{c}\text { Total solids } \\
(\% w / w)\end{array}$ & $\begin{array}{c}\text { Non fat solid } \\
(\% \mathbf{w} / \mathbf{w})\end{array}$ & $\begin{array}{c}\text { Fat } \\
(\% \mathbf{w} / \mathbf{v})\end{array}$ & $\begin{array}{c}\text { Protein } \\
(\% \mathbf{w} / \mathbf{w})\end{array}$ & $\begin{array}{c}\text { Lactose } \\
(\% \mathbf{w} / \mathbf{w})\end{array}$ & $\begin{array}{c}\text { Ash } \\
(\% \mathbf{w} / \mathbf{w})\end{array}$ & pH \\
\hline Winter $(\mathrm{n}=30)$ & $17.41 \pm 0.54^{\mathrm{a}}$ & $8.89 \pm 0.28^{\mathrm{a}}$ & $7.67 \pm 0.55^{\mathrm{a}}$ & $4.90 \pm 0.26^{\mathrm{a}}$ & $3.99 \pm 0.12^{\mathrm{b}}$ & $0.78 \pm 0.07^{\mathrm{a}}$ & $6.68 \pm 0.11^{\mathrm{a}}$ \\
Spring $(\mathrm{n}=30)$ & $15.61 \pm 0.74^{\mathrm{c}}$ & $8.49 \pm 0.23^{\mathrm{b}}$ & $6.38 \pm 0.66^{\mathrm{b}}$ & $4.03 \pm 0.16^{\mathrm{c}}$ & $4.45 \pm 0.20^{\mathrm{a}}$ & $0.69 \pm 0.07^{\mathrm{b}}$ & $6.45 \pm 0.06^{\mathrm{c}}$ \\
Summer $(\mathrm{n}=30)$ & $15.90 \pm 1.03^{\mathrm{c}}$ & $8.49 \pm 0.27^{\mathrm{b}}$ & $6.70 \pm 0.89^{\mathrm{b}}$ & $4.05 \pm 0.14^{\mathrm{c}}$ & $4.43 \pm 0.25^{\mathrm{a}}$ & $0.66 \pm 0.06^{\mathrm{b}}$ & $6.45 \pm 0.12^{\mathrm{c}}$ \\
Autumn $(\mathrm{n}=30)$ & $16.59 \pm 0.57^{\mathrm{b}}$ & $8.37 \pm 0.25^{\mathrm{b}}$ & $7.40 \pm 0.51^{\mathrm{a}}$ & $4.46 \pm 0.18^{\mathrm{b}}$ & $3.91 \pm 0.21^{\mathrm{b}}$ & $0.77 \pm 0.07^{\mathrm{a}}$ & $6.55 \pm 0.12^{\mathrm{b}}$ \\
Mean $(120)$ & $16.38 \pm 1.01$ & $8.56 \pm 0.32$ & $7.04 \pm 0.84$ & $4.36 \pm 0.40$ & $4.19 \pm 0.32$ & $0.72 \pm 0.08$ & $6.55 \pm 0.13$ \\
\hline
\end{tabular}

$a, b, c$; The difference between mean values with different letter in the same column is statistically significant $P<0.01$.

Table 2. Microbiologic analysis results of Anatolian Buffalo milk (log10 cfu/ml).

\begin{tabular}{lcccccc}
\hline Season & TBC & Coliform & LAB & E. coli & S. aureus & Yeast-Mold \\
\hline Winter $(\mathrm{n}=30)$ & $6.26 \pm 0.37^{\mathrm{b}}$ & $2.83 \pm 0.22^{\mathrm{c}}$ & $5.65 \pm 0.26^{\mathrm{b}}$ & $0.98 \pm 0.13^{\mathrm{b}}$ & $2.32 \pm 0.23^{\mathrm{c}}$ & $2.50 \pm 0.32^{\mathrm{c}}$ \\
Spring $(\mathrm{n}=30)$ & $6.33 \pm 0.19^{\mathrm{b}}$ & $2.90 \pm 0.18^{\mathrm{bc}}$ & $5.77 \pm 0.21^{\mathrm{ab}}$ & $1.15 \pm 0.21^{\mathrm{a}}$ & $2.43 \pm 0.21^{\mathrm{bc}}$ & $2.63 \pm 0.22^{\mathrm{b}}$ \\
Summer $(\mathrm{n}=30)$ & $6.52 \pm 0.23^{\mathrm{a}}$ & $3.11 \pm 0.14^{\mathrm{a}}$ & $5.89 \pm 0.41^{\mathrm{a}}$ & $1.18 \pm 0.15^{\mathrm{a}}$ & $2.62 \pm 0.22^{\mathrm{a}}$ & $2.78 \pm 0.20^{\mathrm{a}}$ \\
Autumn $(\mathrm{n}=30)$ & $6.35 \pm 0.22^{\mathrm{b}}$ & $2.95 \pm 0.17^{\mathrm{ab}}$ & $5.67 \pm 0.28^{\mathrm{b}}$ & $0.92 \pm 0.14^{\mathrm{b}}$ & $2.47 \pm 0.18^{\mathrm{b}}$ & $2.64 \pm 0.19^{\mathrm{b}}$ \\
Mean $(120)$ & $6.36 \pm 0.28$ & $2.95 \pm 0.21$ & $5.74 \pm 0.31$ & $1.10 \pm 0.17$ & $2.46 \pm 0.24$ & $2.63 \pm 0.25$ \\
\hline
\end{tabular}

a,b,c; The difference between mean values with different letter in the same column is statistically significant $P<0.01$

TBC: Total Bacteria Count LAB: Lactic Acid Bacteria

lactic acid bacteria (LAB) count and left for $48-72 \mathrm{~h}$ of incubation under anaerobic conditions at $30^{\circ} \mathrm{C}$ (Gas Generation Kit Oxoid BR 0038) (Harrigan and MacCance, 1976).

Cultivations were made on Tryptone Bile X- Glucuronide Medium (TBX) (Oxoid-CM945) for $E$. coli count and incubated at $44^{\circ} \mathrm{C}$ for 18-24 h (Anonymous, 2001). Egg Yolk Tellurite emulsion (OxoidSR54) was included for $S$. aureus count and performed in Baird Parker Agar (Oxoid -CM275) at $37^{\circ} \mathrm{C}$ for $24-48 \mathrm{~h}$ aerobic conditions (Anonymous, 1999). Cultivations were made on Rose Bengal Chloramphenicol Agar (Oxoid-CM549) for yeast and mold count and incubated at $25^{\circ} \mathrm{C}$ for $72 \mathrm{~h}$ under aerobic conditions (Anonymous, 1987).

\section{Statistical analyses}

The microorganism numbers detected in this study were transferred to base 10 logarithm values and then statistical data was obtained by SPSS statistics software. One way variance analysis was performed to determine the differences between microorganism numbers and chemical parameters in terms of seasons, and Duncan test was applied to determine differences among the means.

\section{RESULTS}

\section{Chemical analysis}

As a result of the chemical analyses of milk samples collected from buffaloes in different seasons, the total solids (TS) $(16.38 \% \pm 1.01)$, non-fat solids (NFS) $(8.56 \pm 0.32)$, fat $(7.04 \% \pm 0.84)$, protein $(4.36 \% \pm 0.40)$, lactose $(4.19 \%$ $\pm 032)$, ash $(0.72 \% \pm 0.08)$ and $\mathrm{pH}(6.55 \pm 013)$ values were determined (Table 1). Generally milk yield was determined to increase in plains, humid and rainy areas, while fat content was found higher in cold and mountainous areas. The data of this study indicated that milk fat and protein contents increase concurrently, while TS, NFS, fat, protein, ash and $\mathrm{pH}$ values are highest in winter, while TS, fat and protein levels are lowest in spring.

\section{Microbiological analysis}

Regardless of seasons, the mean total bacteria count (TBC), coliform bacteria, lactic acid bacteria (LAB), E. coli, $S$. aureus and yeast-mold values $\left(\log _{10} \mathrm{cfu} / \mathrm{ml}\right)$ were determined as $6.36 \pm 0.28,2.95 \pm 0.21,5.74 \pm 0.31,1.10$ $\pm 0.17,2.46 \pm 024$ and $2.63 \pm 0.25$, respectively (Table 2 ).

Contamination levels of milk with TBC, coliform, $S$. aureus and yeast-mold were found lower in winter than in other seasons, while the lowest $E$. coli contamination was detected in autumn. The highest contamination levels with these bacteria were observed in summer. Microbiological values of milk samples were found at similar levels in spring and autumn.

\section{DISCUSSION}

In this study, the mean total solids, non-fat solids, fat, protein, lactose and $\mathrm{pH}$ levels of milk samples collected in different seasons were determined as $16.38 \%, 8.56 \%$, $7.04 \%, 4.36 \%, 4.19 \%, 0.72 \%$ and 6.55 , respectively. Fat, protein and ash contents were determined to decrease in hot summer months, while lactose content was reported to increase (Yöney, 1974). It was reported that buffalo milk contain has higher nutritious values with higher pro- 
protein, fat, lactose and TS than cow milk (Fundora et al., 2001; Lidmark-Manson et al., 2003). Different researchers reported that alimentation, lactation period, milking frequency, milking method and season have important effects on physicochemical parameters of buffalo milk (Sethi et al., 1994; Suman et al., 1998; Sekerden et al., 1999; Boycheva et al., 2002; Waldner et al., 2002).

In this study, the mean lactose level of buffalo milks $(4.19 \% \pm 032)$ was found lower than those reported by Han et al. (2007) and Najdenova and Dimitrov (2003). On the other hand, milk fat is the most changeable milk component. Fat content is affected by many factors. The most important factors are seasonal change and lactation period. Fat, protein and ash contents tend to increase in winter, and milk yield is reported to increase in the later periods of lactation, while fat and protein contents decrease. It is also reported that habitat and feeding pattern are quite effective on milk fat and protein levels, and milk protein and NFS contents of animals grazing in summer are higher than those of animals closed-fed in winter (Yöney, 1974; Sevi et al., 2004). In this study, the mean fat $(7.04 \pm 0.84 \% \mathrm{v} / \mathrm{v})$, total solids $(16.38 \pm 1.01 \% \mathrm{w} / \mathrm{w})$ and protein $(4.36 \pm 0.40 \% \mathrm{w} / \mathrm{w})$ contents are slightly lower than those reported by Najdenova and Dimitrov (2003) and Han et al. (2007). Similar results were reported by Sarfarz et al. (2008) and Çelik et al. (2001), but the values of the present study were higher than found by Kanwal et al. (2004). On the other hand, Ariota et al. (2007) reported fat and protein contents of buffalo milk as 8.71 and $3.86 \%$, respectively, and $\mathrm{pH}$ as 6.58 .

The mean ash values $(0.72 \pm 0.08 \% \mathrm{w} / \mathrm{w})$ of Anatolian buffalo milk are similar to the values reported by Celik et al. (2001) and Sarfarz et al. (2008), but higher than the value found by Sekerden and Avsar (2008). The mean $\mathrm{pH}(6.55 \pm 0.13)$ of Anatolian buffalo milk is similar to the values reported by Han et al. (2007) and Sekerden and Avsar (2008), but higher than those of Aurelia et al. (2009).

Variance analysis was used to investigate chemical composition. Total solids, protein, non- fat solids and $\mathrm{pH}$ values were significantly higher $(p<0.01)$ in winter than in other seasons. On the other hand, the lactose content was found higher $(p<0.01)$ in spring and summer than in winter and autumn. The mean fat and ash contents were found highest in winter and autumn.

Similar to milk components, microbiological quality of milk changes by ambient temperature. In this study, the mean total bacteria count (TBC), coliforms, lactic acid bacteria, E. coli, S. aureus and yeast-mold $\left(\log _{10} \mathrm{cfu} / \mathrm{ml}\right)$ levels were determined as $6.36 \pm 0.28,2.95 \pm 0.21,5.74 \pm$ $0.31,1.10 \pm 0.17,2.46 \pm 024$ and $2.63 \pm 0.25$, respectively, and microorganism load was determined to increase in warm months.

The Turkish National Standard (TSE 1018) for TBC was $1.0 \times 10^{5} \mathrm{cfu} / \mathrm{ml}$ for raw cow milk. The EU specification (EU Directive 92/46/EEC, 2004) for raw buffalo milk is an average of $5 \times 10^{5} \mathrm{cfu} / \mathrm{ml} \mathrm{TC}$. In this study, the mean
TBC was determined as $2.30 \times 10^{6} \mathrm{cfu} / \mathrm{ml}$. This level is higher than both the TSE and EU standards. The main reason for these relatively higher counts of TBC should be ascribed to poor hygiene conditions during milking, collection and transport.

$S$. aureus may access bulk milk either by direct excretion from the udder with clinical and subclinical staphylococcal mastitis, or by fecal contamination (Callon et al., 2008). Interchange of staphylococcal strains and poor microbiological quality of raw milk may be attributed to skin particles in the environment and poor sanitary practice (Normanno et al., 2007).

In another study carried out in China, TBC, LAB, yeastmold, coliforms, E. coli and S. aureus $\left(\log _{10} \mathrm{cfu} / \mathrm{ml}\right)$ levels in 120 buffalo milk samples were determined as $5.594 .62,1.79,2.42,1.53$ and 1.68, respectively (Han et al., 2007). Coroian et al. (2010) reported mean coliform bacteria, yeast-mold and aerobe mesophile general creature levels in 42 Romanian buffalo milk samples as 4.96 $\pm 0.45 / \mathrm{ml}, 633.47 \pm 0.01 / \mathrm{g}$ and $4.46 \pm 0.11 \times 10^{5} / \mathrm{ml}$, respectively and they also determined $3.27 \mathrm{log} \mathrm{cfu} / \mathrm{ml}$ of $E$. coli in three samples. According to the results of this study, coliform, E. coli and yeast-mold levels were lower than those reported by Coroian et al. (2010); however, TBC level was found higher. The same researchers carried out a study on Murrah buffalo species and determined coliform, E. coli, S. aureus and yeast-mold levels $\left(\log _{10} \mathrm{cfu} / \mathrm{ml}\right)$ as $3.95 \pm 0.07,1.80 \pm 0.23,1.80 \pm 0.23$ and $1.33 \pm 0.46$, respectively. Accordingly, coliform and $E$. coli levels were lower than those determined in the present study, while $S$. aureus and yeast- mold levels were higher. Similarly, Desmasures et al. (1997) studied cow milk in different seasons, and reported that TBC, LAB, yeast, coliform and $S$. aureus levels $\left(\log _{10} \mathrm{kob} / \mathrm{ml}\right)$ were $7.1 \times 10^{3}$, $1.8 \times 10^{2}, 7.2 \times 10^{1}, 5.7 \times 10^{1}$ and $4.5 \times 10^{2}$, respectively, in winter, while these levels were determined as $8.6 \times 10^{3}$, $1.8 \times 10^{2}, 8.4 \times 10^{1}, 7.7 \times 10^{1}$ and $3.5 \times 10^{2}$ in summer; accordingly, the levels determined in the present study in winter period were lower than those reported by Desmasures et al. (1997). Considering summer levels, TBC was found high, while others were low. Similarly, Ali et al. (2010) determined mean TBC, LAB, coliform, E. coli and $S$. aureus levels in cow milk as $5.86 \pm 0.31,4.47 \pm 0.44,2.76 \pm$ $0.18,1.63 \pm 0.20$ and $1.92 \pm 0.47$, respectively.

In another study on raw buffalo milk samples, TBC, $E$. coli, and yeast levels $\left(\log _{10} \mathrm{cfu} / \mathrm{ml}\right)$ were determined between $3.4 \times 10^{5}-4.0 \times 10^{7}, 2.0 \times 10^{1}-1.7 \times 10^{4}$ and $2.7 \times 10^{2}$ $1.7 \times 10^{4}$, respectively (Braun and Preuss, 2007) compared with this study. LAB constituted a major part of the microflora with an average of $5.74 \pm 0.31 \mathrm{log} \mathrm{cfu} / \mathrm{ml}$ (Han et al., 2007) and mean LAB level in buffalo milk was reported as $4.62 \pm 0.12 \mathrm{log} \mathrm{cfu} / \mathrm{ml}$ (Lingathurai et al., 2009) and $4.46 \pm 0.44 \mathrm{cfu} / \mathrm{ml}$, while it was found $4.47 \pm$ $0.44 \mathrm{cfu} / \mathrm{ml}$ in raw cow milk (Ali et al., 2010). Boycheva et al. (2002) observed that $L A B$ was predominant in Bulgarian buffalo milk. High level of $L A B$ in raw milk would result in undesired fermentative acidity, and it is sugges- 
ted to take effective precautions for preventing this kind of spoilage (Han et al., 2007).

Chemical composition of buffalo milk provides perfect opportunities for the development of local milk industry and providing nutrient element needs of humans. In addition, the presence of pathogens, indicators and index microorganisms in raw milk and products made of inadequately heat-treated milk could pose a threat for public health.

Livestock enterprises making milk production are composed of family enterprises in villages and towns with large numbers. Small sized production units have difficulty in obtaining inputs and services like adequate shelter, feed, technical information, veterinary services for buffalo and cow dairy production. It is possible to precisely organize hygienic and technological stages from production to consumption of milk and milk products only when all potentials are combined. In this regard, the principal that quality milk comes from healthy udder, healthy animal and clean environment gains great importance.

The important rule in food processing is the good quality of raw material. A good quality of end product cannot be obtained from a raw material with poor hygienic quality. Spoilage process of milk starts with milking. The previous studies confirmed that milk hygiene does not receive enough attention in Turkey. Considering the unhealthy conditions in milk production and other contamination sources in milk processes, milk can be a conveyor of pathogens threatening public health. Microorganisms cause rapid souring, spoilage and undesired color, taste and bitterness in milk and thus resulting in poor quality. It is reported that many epidemic disorders of milk origin are caused by dirty hands of workers in milk production, dirty tools and equipment, insects and dirty water sources. Provision of microbiological quality parameters of raw milk and milk products plays an important role in quality control. It is necessary to minimize technological and economic losses in milk processing and obtain a longer shelf life.

\section{REFERENCES}

Ali AA, Irshad N, Razaz SA, Manahil AA (2010). Microbiological safety of raw milk in Khartoum state, Sudan: 1-Khartoum and Omdurman cities. Pak. J. Nutri., 9(5): 426-429.

Amarjit SN, Toshihiko N. (2003). Role of buffalo in the socioeconomic development of rural Asia: Current status and future prospectus. Anim. Sci. J., (74): 443-445.

Anonymous (1987).General guidance for the enumaration of yeast and moulds. Colony count technique at $25^{\circ} \mathrm{C}$.

Anonymous (2001) International Standart Organisation (16649-2). Microbiology of food and animal feeding stuffs- Horizontal method for the enumeration of B-glucuronidase- positive Escherichia coli. Part 2: Colony-count technique a $44^{\circ} \mathrm{C}$ using 5-bromo-4-chloro-3-indoylbeta-D-glucuronide 07/2001.

Anonymous (2003) International Standart Organisation (ISO 4833). Horizontal method for the enumaration of microorganism. Colony count technique at $30^{\circ} \mathrm{C}$.

Anonymous (1999) International Standart Organisation (ISO 6888-1). Horizontal method for the enumaration of coagulase-positive staphylococci. Technique using Baird-Parker Agar Medium.
Anonymous (1993). International Standart Organisation (ISO 7402). General guidance for the enumaration of Enterobacteriaceae. Colony count technique.

Ariota B, Campanile G, Potena A, Napolano R, Gasparrini B, Neglia GL, DiPalo R (2007). Ca and P in buffalo milk: curd yield and milk clotting parametters. Ital. Anim. Sci., 6(6): 497-499.

ASUD (2010). Packed milk ve milk products industrialists association. Milk industry report of world and Turkey.

Atasever S, Erdem H (2008). Buffalo breeding and its future in Turkey. Ondokuz Mayıs Univ. Agri. Fac. J., 23(1): 59-64.

Aurelia P, Cristian C, Camelia R, Vioara M, Gheorghe M (2009). The study of the main parameters quality of buffalo milk, 10(3): 201-206,

Barron L, Labastida E, Perea S, Chavarri F, Vega C, Vicente M, Torres M, Najera A, Virto M, Santisteban A, Perez-Elortonto F, Albisu M, Salmeron J, Mendia C, Torre P, Ibanez C, Renobales M (2001). Seasonal changes in the composition of bulk raw ewe's milk used for Idiazabal cheese manufacture. Int. Dairy J., 11: 771-778.

Bilal MQ, Suleman M , Raziq A (2006). Buffalo: Black Gold of Pakistan. Livestock Res. Rural Development, 18(9): 128.

Boycheva S, Dimitrov T, Tsankova M, Iliev T (2002). Investigaion on microflora of buffalo milk. 8, 279-282, 2002.

Braun PG, Preuss SE (2007). Microbial quality of water buffalo milk and milk products in Germany. Milchwissenschaft, 62(3): 226-228.

Callon C, Gilbert FB, Cremoux RD, Montel MC (2008). Application of variable number of tandem reat analysis to determine the origin of $S$. aureus contamination from milk to cheese in goat cheese farms. Food Control, 19: 143-150.

Chatterjee SN, Bhattacharjee I, Chatterjee SK, Chandra G (2006). Microbiological examination of milk in Tarakeswar, India with special reference to coliforms. Afr. J. Biotechnol., 5: 1383-1385.

Coroian A, Coroion CO, Vodnar DC, Trif M (2010). Study on the main microbiological traits in Romanian buffalo milk. Bioflux, 2(2): 92-98.

Çelik Ş, Bakırcı I, Özdemir C, Özdemir S (2001). A study on teh physicochemical properties of domestic buffalo milk breeded in Erzurum plain. Atatürk Univ. Agri. Fak. J., 32(1): 77-82.

Desmasures N, Bazin F, Guegen M (1997). Microbiological composition of raw milk from selected farms in the Camembert region of Normandy. J. Appl. Microbiol., 83: 53-58.

EU Directive 92/46/EEC (2004). Health rules fort he production and placing on the market of raw milk heat-treated milk and milk-based products. EU: EU Directive.

Fernando RS, Spahr SL, Jaster EH (1983). Comparacion of electrical conductivity of milk with other indirecty methods for detection of subclinical mastitis. J. Dairy Sci., 68: 449-456.

Fundora O, Gonzalez ME, Lezcano O, Montejo A, Pompa N, Enriquez AV (2001). A comparative study of milk composition and stability of Murrah river buffaloes and Holstein cows grazing star grass. Cuban J. Agri. Sci., 35: 219-222.

Haenlein G (2003). Nutritional value of dairy products of ewe and goat milk..

Hamman J, Gyodi P (1994). Effects on milk somatic cell count and milk conductivity of short-term non-milking of lactating quarters of cow. J. Dairy Res., 61(3): 317-322.

Han BZ, Meng Y, Li M, Yang YX, Ren FZ, Zeng QK, Nout MJR (2007). A survey on the microbiological and chemical composition of buffalo milk in China. Food Control, (18): 742-746.

Harmon RJ (1994). Physiology of mastitis and factors affecting somatic cell counts. Symposium: Mastitis and genetic evaluation for somatic cell count. J. Dairy Sci., (77): 2103-2112.

Harrigan WF, MacCance MEC (1976). Laboratory Methods in Microbiology. Academic Press, London and New York.

Hartet P, Beaudeau F, Seegers H, Fourichon C (1999). Reduction in milk yield associated with somatic cell counts up to $600.000 \mathrm{cells} / \mathrm{ml}$ in French Holstein cows without clinical mastitis. Livest Prod. Sci., (61): 33-42.

Jayarao BM, Henning DR (2001). Prevalence of Foodborne Pathogens in Bulk Tank Milk. J. Dairy Sci., 84(10): 2157-2162.

Kanwal R, Ahmed T, Mirza B (2004). Comparative analsis of quality of milk collected from Buffalo, Cow, Goat and Sheep of Rawalpindi/Islamabad region in Pakistan. Asian J. Plant Sci., 3(3): 300-305.

Kilic A, Kilic S (1994). Feeding and milk. Bilgehan Press, Izmir, 1994. 
Lacroix C, Verret P, Paquin P (1996). Regional and seasonal variations of nitrogen fractions in commingled milk. Int. Dairy J., (6): 947-961.

Lindmark-Mansson H, Fonde'n R, Pettersson HE (2003). Composition of Swedish dairy milk. Int. Dairy J., (13): 409-425.

Lindmark-Mansson $\mathrm{H}$, Svensson U, Paulsson M, Alden G, Frank B, Johnson G (2000). Influence of milk components, somatic cells and supplemental zinc on milk process ability. Int. Dairy J., (109): 423433.

Lingathurai S, Vellathurai P, Vendan SE, Anand AAP (2009). Acomparative study on the microbiological and chemical composition of cow milk from different locations in Madurai, Tamil Nadu. Indian J. Sci. Technol., 2(2): 51-54.

Lock AL, Garnsworthy PC (2003). Seasonal variation in milk conjugated linoleic acid and desaturase activity in dairy cows. Livest Prod. Sci., (79): 47-59.

Ma Y, Ryan C, Barbano DM, Galton DM, Rudan MA, Boor KJ (2000). Effects of cell count on quality and shelf-life of pasteurized fluid milk. J. Dairy. Sci., (83): 264-274.

Najdenova N, Dimitrov T (2003). Technological qualities of buffalo milk from the Bulgarian Murrah breed for production of Bulgarian yoghurt. J. Anim. Sci., 40(5): 33-35.

Ng-Kwai-Hang, KF, Hayes JF, Moxley JE, Monardes HG (1984). Variability of test-day milk production and composition and relation of somatic cell counts with yield and compositional changes of bovine milk. J. Dairy. Sci., 67: 361-366.

Normanno G, Corrente M, La Salandra G, Dambrosio AÇ, Quaglia NC., Parisi A, Greco G, Bellacicco AL, Virgillo S, Celano GV (2007). Methicillin-resistant Staphylococcus aureus (MRSA) in foods of animal origin product in Italy. Int. J. Food Microbiol., (117): 219-222.

Oliver SP, Jayarao BM, Almeida RA (2005). Foodborne pathogens in milk and dairy farm environment food safety and public health environment. Food. Pat. Dis., (2):115-129.

Parekh TS, Subhash R (2008). Molecular and bacteriological examination of milk from different milch animals with special reference to coliforms. Current Research in Bacteriology, 1: 56-63

Sarfarz A, Gaucher I, Rousseau F, Beaucher E, Piot M, Grongnet JF, Gaucheron $F$ (2008). Effect of acidification on physico-chemical charecteristics of buffalo milk: A comparison with cow's milk. Food Chem., 106 (1): 11-17.

Sekerden O (1999). Effects of calving season and lactation order on milk yield and milk components in Simmental cows. Turk. J. Vet. Anim. Sci., (23): 79-86.

Sethi RK, Khatkar MS, Kala SN, Tripathi VN (1994). Effect of pregnancy on milk constituents during later stages of lactation in Murrah Buffaloes. Proc. 4th. World Buffalo Cong. San Paolo.
Sevi A, Albenzio M, Marino R, Santillo A, Muscio A (2004). Effects of lambing season and stage of lactation on ewe milk quality. Small. Rum. Res., (51): 251-259.

Sevi A, Annicchiarico G, Albenzio M, Taibi L, Muscio A, Dell'Aquila S (2001). Effects of solar radiation and feding time on behavior, immune responses and production of lactating ewes under high ambient temperature. J. Dairy Sci., (84): 629-640.

Soysal İ (2006). Production of buffalo and its products. Tekirdağ Univ Agri Fac, Department of Animal Husbandry, Lectures Notes. Tekirdağ

Spanghero M, Susmel P(1996). I. Dairy Res, 63(4): 629-633.

Suman CL, Saxena M M, Pandey H S, Dubey P C, Rajendra S, Sanyal M K, et al. (1998). Some factors affectting milk constituents yield of Murrah buffalo. Indian Vet. J., 75 (2): 176-177.

Szita G, Gyetvai B, Szita J, Gyenes M, Solymos N (2008). Synthetic culture media evaluated for detection of coliforms bacteria in milk, cheese and egg melange. Acta Vet. Brno., (77). 143-147.

Sekerden Ö, Tapkı I, Kaya Ş (1999). Under the condition of Hatay province village's effects on Anatolian buffaloes output season and lactating period with milk yield and milk composition changes. Atatürk Univ.Agri. Fac. J (30): 161-168.

Sekerden O, Avsar YK (2008). Milk composition, rennet coagulation, urea content and environmental factors affecting them in Anatolian buffaloes. 49(2): 7-14.

TUIK (2011). Turkish Statistical Institute.

Turkish Standard (2002). Raw milk of cow TS 1018.

Waldner DN, Stokes SR, Jordan ER, Looper ML (2002). Managing milk composition: Normal sources of variation.

Wells JG, Shipman LD, Greene KD, Sowers EG, Green JH, Cameron DN, Downes FP, Martin ML, Griffin PM, Ostroff SM (1991). Isolation of Escherichia coli serotype $\mathrm{O} 157: \mathrm{H} 7$ and other Shiga-like-toxinproducing E. coli from dairy cattle. J. Clin. Microbiol., (29): 985-989.

Yöney Z (1974). Milk Chemistry. Ankara Univ. Agric. Fac. Publication, No. 530, Textbook: 135, Ankara. 